\title{
O leitor e o espectador nas malhas da ficção de Ressurreição, A mão e a luva e Helena
}

\author{
Juracy Assmann Saraiva* \\ Debora Bender**
}

\begin{abstract}
RESUMO
O artigo analisa os romances Ressurreição, A mão e a luva e Helena, publicados por Machado de Assis, entre 1872 e 1876, e cuja diegese abrange o período que vai de 1850 a 1862, para apreender significações que a menção a autores, obras literárias, espetáculos teatrais e musicais agregam às narrativas e para abstrair a representação da sociedade brasileira que essas referências instalam. Elas convidam o receptor a transcender a história narrada para participar das reflexões do escritor sobre o contexto socioestético e a integrar a ficção ao mundo do real; simultaneamente, revelam a importância das experiências de Machado de Assis como leitor e espectador na produção de seus textos.
\end{abstract}

Palavras-chave: Machado de Assis. Ficção. Contexto socioestético. Remissões intertextuais. Ressurreição. A mão e a luva. Helena.

\section{Recíprocas influências entre obra e contexto}

O estudo da obra de um autor pode ser associado ao contexto histórico, social e estético em que ele se situa, pois o meio interfere em suas concepções e, consequentemente, se reflete em sua produção. Instâncias de legitimação da leitura e da literatura, bem como obras em circulação e eventos artísticos, contribuem para a formação do escritor e para seu reconhecimento como homem das letras. Simultaneamente, suas produções reconstituem o horizonte em que ele se situa, uma vez que expressam o diálogo que estabelece com práticas culturais, com processos de institucionalização da literatura, da música, da dramaturgia, com autores e obras.

\footnotetext{
* Universidade Feevale. Artigo produzido no âmbito do projeto "Reflexões poéticas de Machado de Assis, expressas por menções à música e à dramaturgia: o enlace entre texto e contexto", que conta com apoio do CNPq.

** Doutoranda do Programa de Pós-graduação em Processos e Manifestações Culturais da Universidade Feevale (RS) e bolsita da CAPES.
} 
Em sua ficção, Machado de Assis concede um espaço significativo à correlação entre o "mundo possível", nela instituído, e elementos do âmbito das artes, compondo narradores e outras personagens que são leitores ou apreciadores de espetáculos artísticos. Esse aspecto demonstra que a experiência do escritor como sujeito histórico pode constituir via de análise e de reflexão sobre as circunstâncias que envolvem o fazer artístico e sobre esse mesmo processo enquanto manifestação sócio-histórica, interferindo, pois, tanto no momento da produção da obra quanto no de sua recepção.

Sob o ângulo da literatura, a menção, nas narrativas machadianas, a personagens, autores e obras literárias revela o leitor atento, perseverante e crítico, que constrói sua ficção fundamentado-a em um ato de leitura que migra dos livros para a realidade e dessa para aqueles, em uma troca contínua. O próprio ato de leitura é representado, seja porque Machado reproduz uma prática socialmente valorizada, seja porque institui personagens leitoras, em relação às quais os livros que elas leem, ou os que lhes são correlacionados pelo narrador, estabelecem relações metonímicas. Paralelamente, as invocações do narrador ao leitor reproduzem o processo de leitura, instalando ora um clima de cumplicidade ora de afastamento entre os interlocutores textuais; essas estratégias de comunicação, previstas pela narrativa, funcionam como projeção do leitor idealizado pelo autor e como modelo do comportamento esperado do leitor empírico, traduzindo, igualmente a preocupação de Machado com o ato de leitura.

Por sua vez, as menções ao campo da música e da dramaturgia deixam transparecer o conhecimento de Machado de Assis sobre essas duas formas de expressão e também evidenciam práticas culturais da sociedade do Rio de Janeiro da segunda metade do século XIX. Ao referir compositores, obras, ritmos, atores e atrizes em sua ficção, o escritor introduz elementos que se correlacionam à realidade e à estrutura significativa do texto, mas, igualmente, faz uma apreciação valorativa em relação a eles, instituindo um exercício crítico acerca da produção estética. Dessa forma, as remissões a manifestações artísticas, assim como os enunciados metatextuais, promovem o desdobramento do texto sobre si mesmo e põem em relevo concepções a respeito da literatura, da música e da dramaturgia, sendo marcos que possibilitam ao leitor reconstituir reflexões deflagradas pelo escritor diante do ato de escrita. Portanto, as menções de Machado de Assis à leitura, à literatura e a outras artes provocam reflexões de natureza estética e sociológica, pois introduzem questões relativas à sua correlação com o momento histórico e às funções que a elas são atribuídas pela sociedade. 
Com base nesses pressupostos, o presente artigo analisa os romances Ressurreição, A mão e a luva e Helena, publicados por Machado de Assis, entre 1872 e 1876, a fim de apreender significações que a menção a autores, obras, espetáculos musicais e teatrais agrega à narrativa, e para abstrair avaliações críticas do escritor, bem como a representação da sociedade brasileira que essas referências instalam.

\section{Leitor e espectador nas malhas da ficção}

O tempo, relativamente curto - 1872, 1874 e 1876 - que separa a publicação dos três romances aqui enfocados - Ressurreição, A mão e a luva e Helena -, bem como a amplitude temporal dos eventos diegéticos, que se estendem por 12 anos, indo de 1850 a 1862, permitem pressupor, pela identificação de menções intertextuais, elos capazes de correlacionar a escrita ficional de Machado de Assis a dados do contexto estético-cultural.

Ressurreição, primeiro romance machadiano, veio a público em 1872, ano que está mencionado na advertência, e esse constitui o demarcador temporal a que o narrador se refere no incipit da narrativa e em seu epílogo:

Naquele dia, - já lá vão dez anos! - o Dr. Félix levantou-se tarde, abriu a janela e cumprimentou o sol. (ASSIS, 1986, p. 118 destaques nossos).

Dez anos volveram sobre os acontecimentos deste livro, longos e enfastiados para uns, ligeiros e felizes para outros, que é a lei uniforme desta mofina sociedade humana. (ASSIS, 1986, p. $194-$ destaques nossos).

A correlação do tempo ficcional com a data da advertência parece ser uma das estratégias a que Machado recorre para instituir a verossimilhança da narrativa, cujas ações, situadas, portanto, em 1862, e registradas dez anos depois, abrangem um período realtivamente curto, sem que haja a presença incisiva de anacronias ou de elipses diegéticas significativas. Paralelamente, Ressurreição apresenta um enredo pouco denso, marcado pela repetição de situações, fugindo, portanto, ao padrão das narrativas em voga, de que Fanny, de Ernest Feydeau, é exemplo. Todavia, o objetivo do escritor de proceder a uma análise psicológica, por meio do "esboço de uma situação e o contraste de dous caracteres" (ASSIS, 1986, p. 117), e de representar uma personagem caracterizada pela irresolução, pela dúvida e pela desconfiança em relação aos que a cercam, é alcançado. Esse objetivo dá forma à tese, sustentada pela frase de Shakespeare, inscrita na advertência em inglês e 
parcialmente retomada no epílogo em português: "Nossas dúvidas são traidoras / E nos fazem perder o bem que muitas vezes poderíamos conquistar, / Por medo de tentar." (ASSIS, 1986, p. 117). A concentração na análise psicológica, porém, não elide aspectos que remetem à sociedade brasileira da década de 1860, em que o comportamento sexualmente licencioso se desenvolve paralelamente a rígidas convenções morais.

A mão e a luva, segundo romance de Machado de Assis, fora publicado no jornal $\mathbf{O}$ Globo, paulatinamente, entre 26 de setembro e 3 de novembro de 1874 , e sua edição em livro ocorreu ainda no mês de novembro, sendo feita por Gomes de Oliveira \& Cia, empresa que também pertencia aos proprietários do jornal. O tempo da diegese inicia-se em 1853, mas ocorre uma elipse de dois anos, tempo em que a personagem Estevão faz o curso de Direito em São Paulo, centrando-se as ações em 1855. Portanto, há um intervalo de dois anos entre a publicação de um e outro romance, e de pouco mais de uma década entre o tempo da diegese de uma e outra narrativa.

Ao contrário de Ressurreição, cujo final melancólico reafirma a infelicidade do protagonista, que perde o "bem pelo receio de o buscar" (ASSIS, 1986, p. 195), a narrativa de A mão e a luva apresenta um epílogo que corresponde ao ideal romântico, alicerçado na valorização do amor e do casamento. A despeito disso, a motivação dos protagonistas, Guiomar e Luís, orienta-se pelo desejo de ascensão social, sendo o casamento uma oportunidade para alcançar novo patamar nos rígidos esquemas de classe. Portanto, embora se coadune com uma perspectiva idealizadora das relações amorosas, a trama revela os interesses que a elas subjazem, denunciando, ainda, relações de dependência na sociedade brasileira e os subterfúgios de que os subalternos se valem para sobrepor-se a sua condição. Sob esse aspecto, o título do romance sintetiza o posicionamento crítico do autor, que reúne, sob o vínculo do matrimônio, duas ambições que se ajustam, uma à outra, como uma luva se ajusta à mão para a qual foi feita.

O romance Helena foi publicado, originalmente, em fascículos, no jornal $\mathbf{O}$ Globo, entre agosto e novembro de 1876 e, neste mesmo ano, sua primeira edição em livro foi editada pela livraria Garnier. A narrativa começa com a morte do conselheiro Vale, em $1850^{1}$, e suas ações ocorrem neste mesmo ano. Elas incluem o reconhecimento de Helena como filha do conselheiro e sua aceitação pela família,

1 Marta de Senna explica que, por um problema na impressão da primeira edição do livro, em 1876, a data da morte do Conselheiro foi registrada, na segunda edição, de 1905, como sendo abril de 1859, e não 1850 . Segundo a pesquisadora, o erro foi multiplicado nas edições futuras, mas a data correta é a de 1850 , tal como está na primeira edição, devido ao registro de Helena, no desenho que oferece a Estácio no capítulo XI: julho de 1850. SENNA, Marta de. Romances e contos em hipertexto. Disponível em: http://www.machadodeassis.net/hiperTx_romances/obras/helena.htm. Acesso em: 20 abr. 2014. 
a velada paixão entre Helena e Estácio, o horror desse ao tomar conhecimento de que ama sua suposta irmã, a descoberta da mentira em relação à paternidade de Helena e a morte da protagonista.

O romance tematiza, pois, o incesto, delito reprovado pela religião e pela moral e que, por sua dimensão assustadora, exige o sacrifício de uma vítima inocente, no caso, Helena. Paralelamente, ele traduz normas sociais, "que existem para manter a aparência de normalidade e probidade a ser transmitida pelo comportamento das pessoas" (ZILBERMAN, 2012, p. 170), como o da preservação do reduto familiar, cuja integridade, ainda que aparente, deve ser defendida. Dessa forma, Helena explicita que, na sociedade brasileira da década de 1850, relações extramatrimoniais, ainda que frequentes, não devem ser publicamente reconhecidas, tampouco deve ser assumida a paternidade de filhos gerados fora do casamento.

Sob esse ângulo, a narrativa machadiana desnuda o comportamento hipócrita da sociedade, revelado por meio do aprisionamento das personagens a padrões sociais. Todavia, ao transformar a protagonista em vítima, a narrativa não só adota a norma social - já que, devido às circunstâncias, o final feliz da relação amorosa entre Estácio e Helena seria impossível - mas também a corrói, mostrando sua inadequação à realidade. Porém, a denúncia do conflito entre a norma e sua vigência se dá de forma implícita e pode ser mais bem apreendida pela elucidação de aspectos peculiares às personagens e ao contexto social, os quais são sublinhados por remissões intertextuais.

Embora tratem de temas distintos e representem situações de diversa intensidade emocional, indo do desenho de uma relação amorosa frustrada, devido a um defeito moral do protagonista, e da concretização do ideal de vida burguês, alicerçado no casamento e na ascensão social, à ameaça de uma relação incestuosa, Ressurreição, A mão e a luva e Helena registram aspectos em comum. A evidência da crítica social, pela exposição de suas contradições; a complexidade psicológica das personagens, cujas motivações internas são delineadas; a opção pelo processo de narração onisciente - que se alterna com manifestações do narrador intruso, particularmente nos dois primeiros romances, e com a focalização interna, mais evidente em Helena, ao adotar a perspectiva das personagens, esses são traços desses romances, ainda que cada um deles assuma configurações peculiares. Paralelamente, o recurso à intertextualidade, por meio da utilização de citações e alusões à literatura, à música e à dramaturgia, são, igualmente, aspectos que integram esses romances entre si e à totalidade da produção ficcional de Machado, constituindo interrogações dirigidas ao leitor e cujas respostas fazem parte da significação textual. 
Em Ressurreição, a advertência da primeira edição declara os vínculos da escrita com o sistema literário, define a linha mestra do processo criativo e antecipa, pela remissão intertextual, o tema a ser desenvolvido na narrativa. Neste paratexto (GENETTE, 2009), Machado se dirige à crítica para solicitar "intenção benévola, mas expressão franca e justa" e, rejeitando o valor de aplausos não fundamentados no mérito, enfatiza a oportunidade de verdades, mesmo amargas, que atendam à "vontade de aprender". O escritor atribui ao tempo ou à maturidade a capacidade de dissipar a presunção dos indivíduos para dotá-los de uma indispensável dose de confiança e declara que a "reflexão" assume seu domínio com a passagem do tempo, condição também exigida para o "estudo". A seguir, distingue o grupo dos gênios, "a quem a natureza deu o poder quase inconsciente das supremas audácias", daqueles que, conhecendo os "modelos", "as leis do gosto e da arte" e a "extensão da responsabilidade", sentem-se tolhidos, embora isso neles desperte uma "ambição refletida". Situando-se entre os últimos, afirma que as "tarefas literárias" são "nobres e consoladoras", "mas difíceis quando as perfaz a consciência". (ASSIS, 1986, p. 116).

A par de outras leituras possíveis, a advertência de Ressurreição destaca a preocupação de Machado de Assis com o ofício da escrita - em que não há lugar para a improvisação e o diletantismo - e, além disso, enfatiza a importância de "modelos", os quais são aqui representados na figura de Shakespeare. Consequentemente, a citação "Nossas dúvidas são traidoras / E nos fazem perder o bem que muitas vezes poderíamos conquistar, / Por medo de tentar" (ASSIS, 1986, p. 116), enaltece o escritor inglês, em cuja obra Machado encontra um exemplo a ser imitado e motivação para sua produção literária. Consequentemente, ela elucida, também, o caráter do escritor, que não se deixa tolher pela dúvida, mas persegue o caminho projetado, por sua ambição pessoal, no campo das letras.

À citação, retirada da peça Medida por medida, cabe, igualmente, introduzir o tema do romance, e essa finalidade é enfatizada pelo narrador quando a inclui no epílogo para explicar o comportamento de Félix. Entretanto, ao contrário da personagem da peça shakesperiana, Isabela - a quem o enunciado é dirigido por Lúcio, que deseja que a jovem tente demover o substituto do duque de Viena, Ângelo, da condenção à morte, imposta ao irmão da jovem -, Félix é pusilânime e visionário ${ }^{2}$ e incapaz de voltar-se para os que o cercam. Assim, enquanto Lúcio encontra em Isabela um coração audaz, generoso e realista, que enfrenta a tirania de Ângelo e contribui para a reconstituição da ordem legal, o protagonista de

2 O termo "visionário" significa, aqui, aquele que crê em ilusões. PINTO, Luiz Maria da Silva. Diccionario da lingua brasileira. Ouro Preto: Typographia de Silva, 1832. Disponível em: http:// www.brasiliana.usp.br/bbd/handle/1918/02254100\#page/1106/mode/1up. Acesso em: 25 maio 2014. 
Ressurreição não encontra a felicidade porque "seu coração, se ressurgiu por alguns dias, esqueceu na sepultura o sentimento da confiança e a memória das ilusões" (ASSIS, 1986, p.195). A remissão à peça de Shakespeare ganha, porém, no romance, uma função mais ampla do que a de estabelecer um contraste entre personagens, visto que ela constitui motivo de inspiração da narrativa e fio condutor do desenvolvimento das ações e da composição da personagem.

A natureza suspeitosa da personagem Félix justifica outra remissão a Shakespeare, que se dá no capítulo IX, em que Luís Batista, interessado em conquistar Lívia e sendo conhecedor do temperamento do médico, envia a esse uma carta anônima a cujo recebimento e leitura assiste. A remissão a Otelo - "Não adotou o método de Iago, que lhe parecia arriscado e pueril; em vez de insinuar-lhe a suspeita pelo ouvido, meteu-lha pelos olhos" (ASSIS, 1986, p. 147) - provém do narrador, que deseja acentuar a tirania do amor de Félix por Lívia e o ciúme doentio que o consome, bem como a falta de escrúpulos de Luís Batista, cujas ações e caráter estabelecem a comparação com Iago.

A remissão explícita a Otelo também acontece em Helena, na passagem em que Estácio e Melchior procuram elucidar o segredo da protagonista e vão à casa de Salvador, que supunham ser amante da jovem. Ao relatar seu relacionamento com Ângela, mãe de Helena, Salvador declara ter lido, em sua viagem de navio do Rio Grande do Sul para a Corte, em um volume truncado de Shakespeare, uma frase que lhe soara como uma profecia: "Ela enganou seu pai, diz Brabâncio a Otelo, há de enganar-te a ti também" (ASSIS, 1986, p. 375). Ao introduzir a tragédia, a frase remete, por um lado, à efetiva traição de Ângela, contrariando o que ocorre em Otelo, já que Desdêmona não engana o marido; por outro, expõe a generosidade de Salvador, que justifica a ação da mulher por sua natureza contraditória, "metade freira e metade bailarina" (ASSIS, 1986, p. 377), explicando-a pela adesão a uma fantasia de amor. Esse traço do caráter da personagem também fica expresso na cena em que, vendo a ternura que o Conselheiro dedica à filha, abre mão da paternidade.

A caracterização de Salvador não se esgota, porém, por meio do vínculo com Otelo, uma vez que, para dar a dimensão de seu sofrimento quando ainda tencionava raptar Helena, a personagem faz alusão ao poema "Camões", com que Almeida Garrett introduziu o Romantismo em Portugal'. Salvador recusa o ponto de vista do eu lírico, expresso no poema, segundo o qual "a saudade é um pungir

3 Esclarecendo a relação intertextual, Marta de Senna registra que ela remete ao "poema 'Camões' (Prólogo, v. 1 e 2), de Almeida Garett, (1799-1854), [...]. Eis os versos: 'Saudade! gosto amargo de infelizes/ Delicioso pungir de acerbo espinho, [...]”. SENNA, Marta de. Romances e contos em hipertexto. Disponível em: http://www.machadodeassis.net/hiperTx_romances/obras/helena.htm. Acesso em: 25 maio 2014. 
delicioso", declarando que a afirmação só é possível porque o poeta não consultara seu coração para conhecer a dor e a saudade em que se misturava "a cólera, a cólera da impotência e o desgosto mortal do abandono" (ASSIS, 1986, p. 376). A correlação entre a saudade da personagem e a figurada no poema enfatiza a distância entre a representação poética do sentimento e a de sua experiência, a qual transcende em intensidade aquilo que as palavras conseguem traduzir, sendo, pois, acentuado o sofrimento da personagem que fora fraudada em seus mais sensíveis afetos. Portanto, vivendo uma intensa dor que não está infiltrada pela fúria, como na da personagem Otelo, Salvador opõe-se a este, e sua generosidade, sofrimento e sacrifício fazem jus ao nome que o escritor lhe atribui, ainda que não consiga libertar a filha do estigma que lhe é imputado por uma paternidade forjada.

$\mathrm{O}$ alcance da significação em Helena enriquece-se por outra incisão vertical que tem a obra de Shakespeare por objeto: "Não, dizia Estácio consigo, não é este o asilo de um Romeu de contrabando" (ASSIS, 1986, p. 353), ao deparar-se com o pajem, Helena e as montarias, que saíam de uma casa velha, a mesma da bandeirinha azul, que fora reproduzida pela moça no quadro com que o presenteara. A menção à peça Romeu e Julieta sugere a existência de uma relação ilícita por parte de Helena e, na tentativa de apagar a suspeita de que a casa, apesar de sua decrepitude, acolheria algum encontro amoroso, Estácio reflete que ela poderia abrigar alguma família pobre, a que Helena viria ajudar. "Mas a suspeita é a tênia do espírito; não perece enquanto lhe resta a cabeça" (ASSIS, 1986, p. 353), e o protagonista busca elucidar o mistério, fazendo-se receber pelo dono da casa.

Ao abandonar a casa do desconhecido, com quem longamente conversara e que lhe parecia ser honesto, Estácio perde-se em conjeturas e, incapaz de discernir entre realidade e aparência, repelindo a ideia do mal e relutando em acreditar no bem, sofre a angústia da dúvida, que o domina "e agitava-o em suas mãos felinas". Assim, o protagonista, "semelhante ao transviado florentino, achava-se no meio de uma selva escura, a igual distância da estrada reta, - diritta via - e da fatal porta, onde temia ser despojado de todas as esperanças" (ASSIS, 1986, p. 357-358). ${ }^{4}$ A remissão ao poema de Dante enfatiza o dilema de Estácio que, diante da aparente culpabilidade de Helena, sofre em função do sentimento amoroso que nutre por ela, embora seja incapaz de compreender esse sentimento. A mácula de Helena, ou seu envolvimento com o homem da velha casa, é, para a personagem, a "fatal porta", aquela que, na entrada do inferno, anuncia: "Deixai toda esperança, ó vós

4 A citação reúne distintos versos do poema de Dante Aliguieri, ocorrendo, portanto, um livre uso deles por parte de Machado de Assis. 
que entrais." (ALIGHIERI, 2005, p. 47). ${ }^{5}$ Todavia, o mesmo trecho conota não só a impossibilidade de Estácio alcançar o céu, ou o amor de Helena, mas também a ausência de lucidez do protagonista. Ele se vê em meio a uma "selva escura", metáfora que corresponde, nas palavras de Padre Melchior, ao véu espesso que se interpõe entre o coração e a consciência do filho do Conselheiro Vale que, cego e surdo, se deixa envolver pela situação criada pelo pai, até que sua natureza trágica se exponha e mostre a face monstruosa.

O tom marcadamente funesto e vinculado à moral cristã, que a relação intertextual de Helena com A divina comédia institui, torna-se mais evidente quando se recupera a menção ao poema de Dante, presente em A mão e a luva. Nesse romance, o narrador comenta o comportamento de Estevão que, mesmo tendo sido preterido por Guiomar, ao reencontrá-la dois anos depois, deixa que uma remanescente faísca reacenda o incêndio de amor que o consumira. Assim, fantasioso e pouco prudente, Estevão anseia por ver aberta a porta que a jovem fechara atrás de si, após o encontro casual de ambos no jardim da Baronesa. A insensatez da personagem é mencionada pelo narrador, que mostra suas visões ditadas pelo desejo e, entre essas, "o obstáculo, aquela porta fechada, que bem podia ser a da città dolente, mas que em todo o caso ele quisera ver franqueada às suas ambições." (ASSIS, 1986, p. 219).

Um paralelo entre os romances, evidenciado por meio das remissões intertextuais, elucida a finalidade que lhes é atribuída pelo autor e orienta sua interpretação. Assim, a menção à Bíblia, que rivaliza quantitativamente com as referências a Shakespeare, demarca, em Ressurreição, o ponto de vista irônico do narrador em face do comportamento das personagens, enquanto, em Helena, traduz a dimensão do conflito, sob um ângulo respeitoso e reverente.

Ao descrever Viana, irmão de Lívia, o narrador afirma: "Era homem essencialmente prático; o seu reino era todo deste mundo" (ASSIS, 1986, p. 137), fazendo alusão à frase enunciada por Jesus, "o meu reino não é deste mundo". (BÍBLIA SAGRADA, João, 18:38). Inserida em um contexto profano, a frase bíblica perde sua seriedade e torna-se cômica, conotando as atitudes de Viana, que coloca o interesse pecuniário e a ascensão social como vetor de suas ações.

A menção a Betsabé, personagem do Antigo Testamento, é, igualmente, reveladora do caráter das personagens, visto que recai sobre Luís Batista e sobre Félix, evidenciando a natureza ardilosa do primeiro e a luxúria de ambas as personagens. No capítulo XX, Batista procura Félix para analisar suas reações

5 ALIGHIERI, Dante. A divina comédia (O Inferno, canto III, verso 9). São Paulo: Landmark, 2005, p.47. 
diante da carta anônima com que ele insinuava a infidelidade de Lívia, mas sob o pretexto de conseguir uma gravura de Betsabéb ${ }^{6}$ que fora adquirida pelo médico, para com ela presentear a amante, cujas feições eram "a cópia exata" das feições da personagem bíblica. Segundo o narrador, "o assunto era o mais ortodoxo possível: a israelita Betsabé no banho e o rei Davi a espreitá-la do seu eirado" (ASSIS, 1986, p. 182). Assim se referindo aos personagens ele chama a atenção do leitor para a inconsistente justificativa da visita de Batista e, simultaneamente, dá uma pista sobre a origem da carta anônima, em que uma alusão à Bíblia visa, por meio de uma metáfora, sugerir uma futura traição de Lívia: "No fim de alguns meses terás um Cireneu ${ }^{7}$ para te ajudar a carregar a cruz, como teve o outro, por cuja razão se foi desta para a melhor.” (ASSIS, 1986, p. 189). Tanto a justificativa da visita quanto o teor da carta anônima deveriam esclarecer Félix sobre as intenções de Batista, porém, movido pela desconfiança, ele se deixa enganar por aquele de quem, de fato, deveria desconfiar. Com efeito, tanto as remissões a Betsabé e a Cirineu quanto a paródia das palavras de Cristo contribuem para instalar um tom jocoso em Ressurreição, cujo título apresenta uma significação literal que é negada pela significação implícita. Entretanto, embora sejam expressas a partir da percepção irônica do narrador, as menções à Bíblia e o título do romance, que também converge para o âmbito semântico do sagrado, introduzindo uma significação às avessas, decorrem da orientação crítica de Machado de Assis, que representa, ficcionalmente, a falsa adesão da sociedade à moral cristã.

No romance Helena, a remissão à Bíblia aparece vinculada aos protagonistas nos capítulos VII e XIV, que se referem a Estácio, e, nos capítulos IX e XIII, que esclarecem circunstâncias ligadas a Helena. A primeira menção dá-se na passagem em que Dr. Camargo apresenta a Estácio a proposta de adesão à carreira política, afirmando o narrador que "Estácio ouviu atento estas vozes com que a serpente lhe apontava para a árvore da ciência do bem e do mal. Menos curioso que Eva, entrou a discutir filosoficamente com o réptill" (ASSIS, 1986, p. 302). O episódio bíblico da tentação de Eva pela serpente elucida o comportamento do Dr. Camargo, cujos ardis para seduzir o futuro genro são bem-sucedidos. Entretanto, Estácio declara que vai entrar na Câmara, comparada a uma cova de leões, sem a convicção do profeta Daniel. A referência à personagem bíblica, que, exilado na Babilônia, continua a cultuar o Deus de Israel, sendo, por isso, encarcerado junto com leões

6 Betsabé é seduzida pelo rei Davi, que se casa com ela depois de ter provocado a morte de seu marido, Urias. A história é narrada no Antigo Testamento, em Samuel (2) 11: 2.

7 Simão Cireneu é a personagem que ajuda Jesus Cristo a carregar a cruz no caminho para o Calvário. A passagem é relatada no Novo Testamento pelos evangelistas Mateus (27: 32), Marcos (15: 21) e Lucas (23: 26). 
(BÍBLIA SAGRADA, Gênesis, 3: 1-6), sublinha a ambição do Dr. Camargo e a pusilanimidade de Estácio, mas sugere também a animosidade que pautava a classe política brasileira, na década de 1850, envolvida com os debates relativos à proibição do tráfico negreiro e à posse de terras.

Os capítulos IX e XIII de Helena, centrados na protagonista, remetem ao Antigo Testamento: o primeiro para expor a generosidade dela e, o segundo, para enfatizar sua angústia. Naquele, o narrador afirma que Helena teria de tocar o coração de Dona Úrsula para conseguir sua afeição, que é alcançada pela dedicação da moça à tia de Estácio, quando essa passa por uma enfermidade. Referindo-se à mudança de Dona Úrsula, que se faz carinhosa e mãe, o narrador declara que a dedicação foi a vara de Horeb, introduzindo a passagem do Antigo Testamento em que Moisés faz jorrar água do rochedo, para, metaforicamente, significar a mudança na atitude de Dona Úrsula e a adoção afetiva de Helena.

No capítulo XIII, Helena sofre a opressão do Dr. Camargo que conhece o segredo de suas visitas à cabana de Salvador e exige que ela aconselhe Estácio a casar-se com Eugênia. Angustiada, a protagonista escreve cartas que rasga e queima em seguida, para, finalmente, recorrer à prece que, nas palavras do narrador, "é a escada misteriosa de Jacó: por ela sobem os pensamentos ao céu; por ela descem as divinas consolações." (ASSIS, 1986, p. 328). Sentindo medo e raiva por um lado, e tristeza, por outro, já que seus sentimentos a respeito do suposto irmão a levam a desejá-lo, Helena busca consolo e inspiração divinas. O leitor, porém, infere que eles não são alcançados, pois o "sono fugira dos olhos de Helena" (ASSIS, 1986, p. 323), cujo drama se revela sem solução.

O dilema da protagonista agudiza-se, e a relação da narrativa com o âmbito da religiosidade é intensificada depois que Estácio dela exige uma explicação sobre a visita à casa de Salvador e, premido pelas circunstâncias ou pelas aparências, instala um tribunal doméstico, no qual o padre Melchior atua como juiz. Nesse julgamento, o próprio Estevão, que se sente ludibriado por Helena, passa de ingênuo e crédulo a culpado, após o padre lhe revelar que ele e a jovem haviam transgredido a lei divina e a lei humana, sem o saber: "São irmãos e amam-se." (ASSIS, 1986, p. 365). A revelação, que a Estácio parece ser um sonho mau ou um funesto equívoco, é justificada por Melchior pela remissão ao evangelho de Mateus (7: 16:), "Pelos seus frutos os conhecereis. Porventura colhem-se uvas dos espinhos, ou figos dos abrolhos?", e explicada pela apropriação da epístola de São Paulo a Tito (1: 15), "para os corações limpos, todas as cousas são limpas" (ASSIS, 1986, p. 364-365). Ambas as passagens contribuem para delinear a situação contraditória de Estácio, cuja propensão ao mal é vista como nefasta herança ou como castigo pelos erros do Conselheiro Vale e cuja falta de compreensão quanto à espúria afeição que sente por Helena é atribuída à pureza de seu coração, 
incapaz de reconhecer a maldade. É na convicção religiosa que o padre encontra o caminho para indicar a Estácio a superação do seu conflito, impelindo-o a atender ao preceito do "Eterno Mestre" e jurar diante do crucifixo, isto é, da "efígie de Deus", que não mais se aproximaria de Helena.

A centralidade do papel de padre Melchior na trama da narrativa legitima as inúmeras remissões à Bíblia; paralelamente, também é sob o ângulo dessa personagem que o incesto é relacionado à poesia trágica, que "pode fazer do assunto uma ação teatral" (ASSIS, 1986, p. 365). A alusão justifica o desfecho da narrativa e a solução para o conflito na morte da protagonista, os quais articulam a representação do contexto ficcional, que se situa entre 1850-1851, com o do momento de sua produção. Nesse período, mudanças se projetavam no cenário nacional, configurado por uma sociedade rigidamente dividida e hierarquizada, sendo as personagens vítimas da estratificação e estreiteza do contexto sócio-histórico. A partir desse aspecto, identifica-se, em Helena, uma crítica sutil de Machado à organização social, cuja superação parcial se avizinhava, mas que exigia para a mudança "um rito de passagem, sendo Helena o objeto do sacrifício" (ZILBERMAN, 2012, p. 177).

A orientação para o trágico, porém, expõe-se como um prenúncio ou uma antecipação para o leitor, no capítulo VI, em que, em meio à banalidade das conversas da hora do chá, Helena declara a Estácio que não se detivera toda a tarde a fazer crochê, pois buscara um livro, mais especificamente, um romance, na estante dele. O diálogo que segue entre ambos estabelece uma oposição entre Paulo e Vírgínia, obra de Bernardin de Saint-Pierre, e Manon Lescaut, de Antoine François Prévost, sendo manifestada, nas reticências de Estácio e na explicação de Helena, a reprovação à história do Cavaleiro Desgrieux e da cortesã Manon. Emergem, assim, nas entrelinhas de um diálogo aparentemente banal, a avaliação das obras: enquanto a de Prévost é considerada moralmente nefasta, em oposição a ela, a de Saint-Pierre é considerada adequada a mulheres em formação. Todavia, ambas as narrativas, entrevistas como subtextos, agregam significados ao romance de Machado: enquanto Manon Lescaut sugere a possibilidade de ser Helena falsa e interesseira, tal qual o fora a amante de Desgrieux, significação sustentada pelas atitudes contraditórias da protagonista, Paulo e Vírgínia prenuncia a relação amorosa entre as personagens, a qual deve ser aniquilada em nome dos padrões de comportamento social. Um e outro texto, particularmente por estarem justapostos, passam a fazer parte do processo narrativo do romance de Machado, resumindo-o e conferindo-lhe uma via de autointerpretação, confirmada pelo epílogo, cujo infortúnio reúne Helena, Virgínia, Manon e seus inconsoláveis amantes. Portanto, o diálogo entre Estácio e Helena opera a analogia, mas o enigma da relação hermenêutica entre as obras só é desvendado pela apropriação progressiva da totalidade da narrativa, por meio da 
qual o leitor percebe a convergência para a tragicidade e o nível metarreflexivo que integra o romance de Machado de Assis aos de Saint-Pierre e do Abade Prévost.

Ainda que não assumam a dimensão reflexiva da mise-em-abyme acima referida, inúmeras outras menções explicitam os vínculos dos romances em análise com obras literárias em circulação. Assim, as Máximas do Marquês de Maricá, livro que o Conselheiro lia antes de sua morte, constitui-se em um prolongamento desse, reforçando a imagem pública de homem respeitável; o Saint-Clair das ilhas com que D. Úrsula se entretém pela centésima vez, coaduna-se com o espírito melancólico da personagem e com a limitação de seus horizontes; ${ }^{8}$ a leitura de Werther, por Estêvão, que, desiludido por experimentar um amor não correspondido, pensa em se matar, acentua a teatralidade de seu comportamento, sendo reveladora de fragilidade moral da personagem. ${ }^{9}$ As obras citadas, ainda que não mereçam avaliações explícitas do narrador - como é o caso do romance de Elizabeth Helme, cuja ampla recepção é referida - constituem o horizonte em que Machado de Assis se situa e com o qual estabelece um diálogo para referendá-lo ou contestá-lo, fazendo de suas narrativas uma extensão de práticas culturais em vigor.

Com efeito, em Ressurreição, em A mão e a luva e em Helena entrecruzam-se não apenas indicações de obras literárias, mas também de outras peças dramáticas além das já referidas, de obras musicais que fazem parte do escopo cultural da sociedade brasileira do período que se entende de 1850 a 1880. No âmbito musical, ganham destaque, em Ressurreição, os compositores alemães Jacques Offenbach e Carl Weber; em A mão e a luva, a ópera Sonâmbula, de Vincenzo Bellini, a ópera Ernani de Giuseppe Verdi e a comédia Os parisienses da decadência, de Théodore Barrière são mencionadas. Igualmente, as disputas entre os admiradores das cantoras Emy La Grua e Anne Charton-Demeur são transferidas para o plano da ficção desse romance, enquanto o Teatro Lírico, inaugurado em $1854^{10}$, e o Ginásio Dramático, em 1855, são espaço de interação social ou do encontro entre

8 "Na seguinte manhã, Estácio levantou-se tarde e foi direto à sala de jantar, onde encontrou D. Úrsula, pachorrentamente sentada na poltrona de seu uso, ao pé de uma janela, a ler um tomo do 'Saint-Clair das Ilhas', enternecida pela centésima vez com as tristezas dos desterrados da ilha da Barra; boa gente e moralíssimo livro, ainda que enfadonho e maçudo, como outros de seu tempo." (ASSIS, 1986, p. 282). "D. Úrsula estava então na sala de costura, relendo algumas páginas do seu 'Saint-Clair', encostada a uma mesa" (ASSIS, 1986, p. 292).

9 "O rapaz acertara de abrir uma página de Werther; leu meia dúzia de linhas, e o acesso voltou mais forte que nunca." (ASSIS, 1986, p. 203).

10 "Foi inaugurado com a encenação da ópera Ernani, de Verdi. Nele se apresentaram importantes cantores de ópera e artistas de teatro, além de concertistas famosos. Segundo alguns estudiosos, foi o berço da ópera no Brasil". SENNA, Marta de. Romances e contos em hipertexto. Disponível em: http://www.machadodeassis.net/hiperTx romances/obras/helena.htm. Acesso em: 25 mai. 2014.

A proximidade entre o evento de inauguração do teatro e o tempo diegético de A mão e a luva permite pressupor que Machado tinha em mente a apresentação da ópera Ernani, daquela temporada lírica. 
personagens; em Helena sobressai a menção a Vincenzo Bellini sendo executado ao piano por Eugênia, e ao Teatro Vaudeville para caracterizar Mendonça, recémchegado da Europa, estabelecendo-se uma correlação entre o universo fictício e a realidade.

Portanto, as menções, no espaço ficcional, a obras e a costumes permitem traçar um desenho da realidade sociocultural do Rio de Janeiro, na segunda metade do século XIX. A valorização da leitura e da literatura, em um período em que poucos sabiam ler; a identificação de obras e de autores em circulação e a razão para sua evidência; o desejo de assimilar costumes e hábitos europeus, de que a aquisição de pianos, a organização de saraus e a frequência ao teatro são exemplo; a prática da religião como uma convenção para atender a expectativas sociais ou como ditame ético e moral; as normas reguladoras do direito, representadas, nas narrativas analisadas, pelas regras matrimoniais e de filiação, são aspectos que remetem à sociedade em que Machado de Assis viveu. Sobre ela incide a crítica do escritor, que, ainda pouco consistente em Ressurreição, progride em densidade até chegar a Helena, onde, todavia, o posicionamento do autor fica resguardado por meio de sutilezas e artifícios que as relações intertextuais ajudam a elucidar.

Sob essa perspectiva, as menções a obras literárias, a espetáculos teatrais e dramáticos, a autores, compositores e artistas, em circulação na segunda metade do século XIX, ganham novo sentido. Transpostas para a ficção, as referências introduzem virtualidades semânticas no espaço diegético que as acolhe: por um lado, constituem suporte à encenação de situações ou à composição de cenários; configuram-se em prolongamento metonímico da personagem, contribuindo para sua caracterização; fazem a intriga avançar. Por outro lado, ao apresentarem os contornos da sociedade representada, elas sugerem apreciações valorativas de Machado, que se situa diante de seu contexto social. Portanto, em sua ficção, Machado convida o leitor a transcender a história narrada para participar de suas reflexões sobre o contexto em que realiza sua produção, integrando a ficção ao mundo do real. A possibilidade de conjugar esses dois âmbitos, ontologicamente distintos, permite que se instale uma compreensão renovada da sociedade do Segundo Império e um novo perfil do escritor, que, entre 1855 e 1880, ainda perseguia as sendas que lhe dariam emergência no cenário da literatura brasileira e ocidental. Essas, porém, já estavam demarcadas pela compreensão da literatura como sistema, pela seleção de modelos a serem seguidos, de que Shakespeare é exemplo, pelo reconhecimento da função social da literatura e da arte e por sua capacidade de observação, de análise e de crítica, aspectos que se fazem presentes em Ressurreição, A mão e a luva e Helena. 


\begin{abstract}
This article analyzes the novels Ressurreição, A mão e a luva e Helena, published by Machado de Assis, between 1872 and 1876, and whose narration covers the period that goes from 1850 to 1862 , The aim is to comprehend the meanings that the reference to authors, literary works, theatrical and musical performances add to narratives and to abstract the representation of Brazilian society that these references establish. They invite the reader to transcend the narrated story in order to participate in the writer's reflections on the socio-aesthetic context and to integrate the fiction to the real world. These references, simultaneously, recognize the importance of Machado de Assis's experiences as a reader and a viewer in the production of his texts.
\end{abstract}

Keywords: Machado de Assis. Fiction. Social-aesthetic context. Ressurreição. A mão e a luva. Helena.

\title{
Referências
}

ALIGHIERI, Dante. A divina comédia. São Paulo: Landmark, 2005.

ASSIS, Machado de. Obra completa. Rio de Janeiro: Aguilar, 1986. V. 1.

BÍBLIA SAGRADA. Erechim: Edelbra, s.d.

GENETTE, Gèrard. Paratextos editoriais. São Paulo: Ateliê Editorial, 2009.

PINTO, Luiz Maria da Silva. Diccionario da língua brasileira. Ouro Preto: Typographia de Silva, 1832. Disponível em:

http://www.brasiliana.usp.br/bbd/handle/1918/02254100\#page/1106/mode/1up. Acesso em: 25 maio 2014.

SENNA, Marta de. Romances e contos em hipertexto. Disponível em: http:// www.machadodeassis.net. Acesso em: 20 abr. 2014.

ZILBERMAN, Regina. Brás Cubas autor, Machado de Assis leitor. Ponta Grossa, PR: Editora UEPG, 2012.

Submetido em: 13 de maio de 2015.

Aceito para publicação em: 09 de outubro de 2015. 
